\title{
Agricultural Information Needs of Small Holder Farmers in Central Agricultural Zone of Nasarawa State
}

\author{
Salau, E.S. ${ }^{1}$; Saingbe, N. D. ${ }^{1}$ and Garba, M. ${ }^{2}$. \\ 1. Department of Agricultural Economics and Extension, \\ Faculty of Agriculture Shabu-Lafia Campus, \\ Nasarawa State University, Keffi. \\ 2. Department of Horticulture, \\ College of Agriculture, Lafia, Nasarawa State. \\ Corresponding Author's email: emmasalau@yahoo.com
}

\begin{abstract}
This study was conducted in the Central agricultural zone of Nasarawa State to investigate the level of farmers' access and use of agricultural information. Data for the study were collected from 120 respondents with the aid of a structured questionnaire. Data analysis was done using descriptive statistics (frequency, percentage and mean scores) for objectives 1, 2, 3 and 4. Objective 5 was achieved using a multiple regression model. Most (41\%) of the respondents were aged between 41 - 50 years and their mean age was 40 years. A greater proportion (39\%) of the respondents had primary education and $15 \%$ were illiterates. Most (77\%) of the respondents were married. Majority (86\%) of them were full time farmers with average farm size of $4.5 \mathrm{ha}$ and mean household size of 8 persons. Majority (94\%) of respondents belonged to one or two social organizations. The mean years of farming experience was 25 years. Only 37\% obtained farm credit of various amounts. The respondents' information needs were numerous and diverse which included information on pests and disease control (61.7\%), sources of improved seeds/seedlings (43.3\%), crop and animal husbandry (42.5\%), sources of farm credit (39.2\%) and marketing information among others. Respondents' most preferred sources of information included produce buyers, input dealers and extension agents. The major constraints to use of various information sources were poor marketing facilities, lack of credit, poor infrastructures as well as poor extension services. It was recommended that governments at all levels should introduce measures that would ensure easy access to credit, agricultural information and market as well as rural infrastructures in line with the transformation agenda.
\end{abstract}

Keywords: Agricultural information needs, Small Farmers

\section{Introduction}

Agricultural information refers to all published and unpublished knowledge on general aspects of agriculture and consists of innovations, ideas and technologies of agricultural practice (Aina, 1990). Agricultural information is needed for overall development of agriculture for the improvement of living standard of farmers. The objective of agricultural transformation agenda can hardly be realized when farmers have no access to information. Having timely and relevant information can make a whole world of difference to farmers' decision and actions.

According to Agbamu (2006), information is an indispensable factor in the practice of farming and it is the basis of extension delivery. The quality of any agricultural information rests solidly on three pillars which are accuracy, timeliness and relevance. Accuracy implies that information is free from bias. Timeliness means that recipients can get information when the need it, while relevance implies whether the piece of information specifically answers the user's questions of what, when, where, who and how? Access to accurate and adequate information is very essential to increased agricultural productivity. Consequently, farmers 
consciously or unconsciously engage in information search in order to fill the information gap and to satisfy their goals.

Agricultural information creates awareness among farmers about agricultural technologies for adoption. It is the first and indispensable step of an adoption process. Agricultural information is usually generated through various sources. According to Aina (1995) and Ozowa (1995) these sources of agricultural information include agricultural research institutes, universities of agriculture and faculties of agriculture in conventional universities, government legislations, agro-based industries and service institutions. It is imperative that the generated information from these sources reaches the intended users and ultimately meets their needs. Aina (1991) and Kaniki (1995) opine that each agricultural information user usually has specific information need based on variables such as education, economic status, geographical location, age, availability of information providers, awareness of the available information providers and access to information providers. Family size and farming experience of the farmers also affects their information needs (Idrisa et al, 2006).

Farmers' agricultural information needs vary from one community to another due to various factors. A better understanding of the specific needs of farmers in each State and community of Nigeria is needed. This will lead to site- specific information and will cater for the specific needs of the farmers in that locality precisely.

The ultimate goal of agricultural extension is to make agricultural information available or accessible to farmers who are in need of it. Agricultural information is one of the essential resources in farm production which is not given reasonable recognition in farm planning and operation. Farmers are forced to learn from little experience existing around them. This is because extension services seem not to be effective and efficient in conveying agricultural information. It is argued that farmers do not adopt an improved technique because they have not heard or did not know anything about the practice. This implies that adequate information enhances rapid technology adoption. Poor infrastructures in the rural areas where the majority of farmers reside also constitute a problem to agricultural information accessibility. Inadequate information on agricultural technologies is a leading reason for poor patronage and adoption by farmers leading to poor agricultural productivity (Idris et al, 2006).

Agricultural information is as important as other resources for agricultural production. This is because in farm management, decisions are guided by information. Acquisition, allocation, coordination and utilization of farm resources may be influenced by the nature and adequacy of information in the farming communities. It is in realization of this that the Federal government of Nigeria introduced the Growth enhancement scheme (GES) under the agricultural transformation agenda (ATA). The aim is to modernize agriculture and make it as a business rather than a development programme. Farmers are expected to use modern channels such as mobile phones and even the Internet (for literate ones) to access agricultural information. According to Natsa (2013), all farmers whether small, medium or large scale, need information and communication systems. Connecting to supermarkets and international markets require that farmers know and meet stringent consumer-driven grades and standards. In today's supply chains, the flow of information from buyers to farmers must be instant, to meet rapidly changing demands. Unless farmers have information at their finger tips, they will lose out on market opportunities. 


\section{Purpose of the study}

The purpose of this study was to examine the level of access and utilization of various sources of agricultural information by farmers in Central Agricultural Zone in Nasarawa state. The specific objectives were to:

1. identify various agricultural information needs of respondents;

2. identify sources of agricultural information mostly utilized by respondents;

3. identify factors militating against access and effective utilization of information sources by respondents, and;

4. determine the effect of selected socio-economic characteristics of the respondents on level of utilization of information sources.

\section{Methodology}

The study was conducted in the Central Agricultural Zone of Nasarawa State Nigeria. It consists of four Local Government Areas, namely Akwanga, Wamba, Kokona and Nasarawa-Eggon with the zonal office at Akwanga. The target population of study was small-scale farmers. Three LGAs out of four LGAs in the zone were purposively selected. These were Akwanga, Nasarawa Eggon and Wamba LGAs. Secondly, 4 farming communities (villages) were randomly selected from each of the three LGAs to give 12 villages. Then 10 small-scale farmers were randomly selected from each of the selected villages to give a total of 120 respondents.

Primary data were collected during the 2011/2012 cropping season with the aid of structured questionnaire. Data analysis was done using the Statistical Package for Social Sciences (SPSS) 15 version. Objectives 1 and 2 were achieved using simple descriptive statistics such as frequency, percentage and mean. Objectives 3 and 4 were achieved using mean scores. Objective 5 was achieved using a multiple linear regression model represented below.

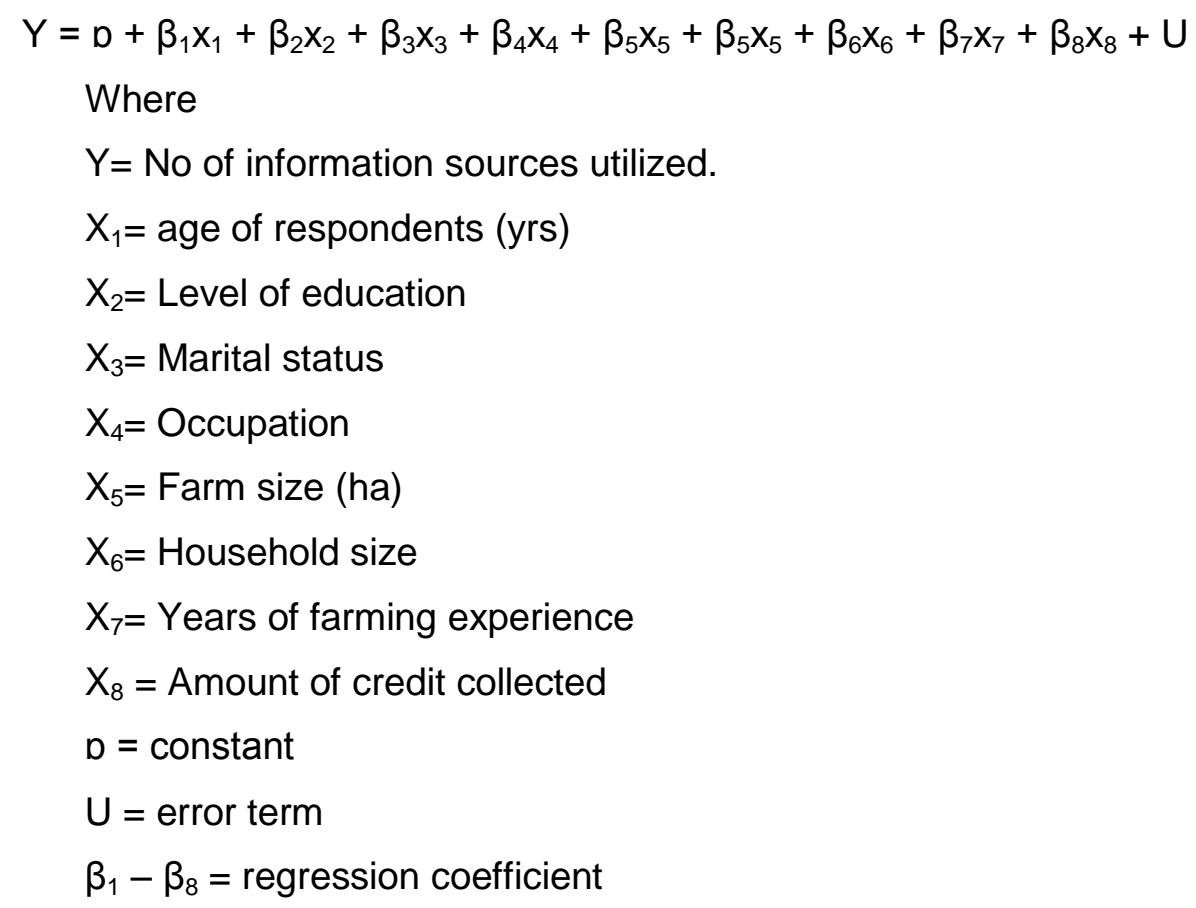




\section{Results and Discussion}

\section{Socio-economic characteristics of the respondents}

Table1shows the distribution of respondents according to their socioeconomic characteristics:

Most $(41 \%)$ of the respondents were aged between 41 - 50 years with a mean age of 40 years. This implies that most of the farmers in the study area were middle aged people who are still strong and energetic. Young people are most likely to utilize modern sources of agricultural information such as mobile phones, television, newspaper and the internet than elderly people. A greater proportion (39\%) of the respondents had primary education, $38 \%$ had secondary education and $15 \%$ were illiterates. Education is quite important in utilization of modern sources of information. Ozowa (1995) noted that the use of technical languages in communicating information needs of rural population is incomprehensible to the illiterate farmers. Majority (77\%) of the respondents were married.

The reason for this is not far-fetched as family labour is a predominant source of labour in Nigerian agriculture and other developing countries of the world.

Majority (86\%) of the respondents were full time farmers. This implies that farming was a dominant occupation of people in the study area. Majority $(68 \%)$ of the respondents had farm sizes ranging between 1 - 5ha. This implies that most farmers in the study area practiced subsistence farming (1-5ha). Most (38\%) of the respondents had household size of between $6-10$ persons. The mean household size of the respondents was about 8 persons. This implies that most of the respondents had small family size. This might also mean less supply of farm labour by family members thereby forcing the farmers to engage hired labour.

Majority (94\%) of respondents belonged to one or two social organizations. This shows that majority of the respondents were fully aware of the benefits of joining social organizations and had taken advantage of such opportunity. Table 1 also shows that a greater proportion $(30 \%)$ of the respondents had farming experience of between $11-20$ years. The mean years of farming experience was 25 years. This implies that most of the respondents were old in the farming business. This might increase their farm management skills and facilitate adoption of innovations.

Majority (63.33\%) of the respondents did not obtain any loan for farm production during the period of study while about $37 \%$ obtained farm credit of various amounts. The result further shows that $20.83 \%$ of the respondents collected credit of between $\mathrm{N} 1,000-50,000$. The average amount of loan taken by the respondents was about N20, 000 which is too small for any tangible farm investment. The fact that most of the respondents did not use farm credit might be due to poor access to this vital production input. 
Table 1: Distribution of respondents according to their socio-economic characteristics

\begin{tabular}{|c|c|c|}
\hline Variables & Percentage $(n=120)$ & Mean \\
\hline \multicolumn{3}{|l|}{ Age (years) } \\
\hline $21-30$ & 24.00 & \multirow{10}{*}{40.3} \\
\hline $31-30$ & 26.00 & \\
\hline $41-50$ & 41.00 & \\
\hline $51-60$ & 5.00 & \\
\hline Above 60 & 4.00 & \\
\hline \multicolumn{2}{|l|}{ Education } & \\
\hline No formal education & 15.00 & \\
\hline Primary education & 39.00 & \\
\hline Secondary education & 38.00 & \\
\hline Tertiary education & 8.00 & \\
\hline \multicolumn{3}{|l|}{ Marital status } \\
\hline Single & 21.00 & \\
\hline Married & 77.00 & \\
\hline Widowed & 1.00 & \\
\hline Divorced & 1.00 & \\
\hline \multicolumn{3}{|l|}{ Major occupation } \\
\hline Farming & 86.00 & \\
\hline Civil servant & 10.00 & \\
\hline Artisan & 4.00 & \\
\hline \multicolumn{3}{|l|}{ Farm size (ha) } \\
\hline $1-5$ & 68.00 & 4.5 \\
\hline $1-5$ & 30.00 & \\
\hline $6-10$ & 2.00 & \\
\hline \multicolumn{3}{|l|}{ Household size } \\
\hline $1-5$ & 37.00 & 7.7 \\
\hline $6-10$ & 38.00 & \\
\hline $11-15$ & 16.00 & \\
\hline $16-20$ & 7.00 & \\
\hline Above 20 & 2.00 & \\
\hline \multicolumn{3}{|l|}{$\begin{array}{l}\text { Membership of social } \\
\text { organizations }\end{array}$} \\
\hline No & 6.00 & 1.2 \\
\hline Yes & 94.00 & \\
\hline \multicolumn{3}{|c|}{ Farming experience (years) } \\
\hline $1-10$ & 15.00 & 24.7 \\
\hline $11-20$ & 30.00 & \\
\hline $21-30$ & 21.00 & \\
\hline $31-40$ & 26.00 & \\
\hline $41-50$ & 5.00 & \\
\hline Above 50 & 3.00 & \\
\hline \multicolumn{3}{|c|}{ Amount of credit collected (N) } \\
\hline Never used credit & 63.33 & $19,891.6$ \\
\hline $1,000-50,000$ & 20.83 & \\
\hline $51,000-100,000$ & 14.17 & \\
\hline Above N100, 000 & 1.67 & \\
\hline
\end{tabular}

Source: Field Survey Data (2011) 


\section{Agricultural information needs of respondents}

Table 2 shows the distribution of respondents based on their agricultural information needs. Majority (61.7\%) of the respondents needed information on methods of pests and disease control, followed by $43.3 \%$ who needed information on sources of improved seeds/seedlings, $42.5 \%$ needed information on improved techniques of crop and animal husbandry, $39.2 \%$ who needed information on appropriate sources of farm credit and $24.2 \%$ who desired marketing information among other information needs. The result shows that farmers' information needs were numerous and diverse. This implies that extension services must address the needs of the farmer in a holistic manner.

Table 2: Distribution of respondents according to their agricultural information needs

\begin{tabular}{|c|c|}
\hline Farm information needs & $\begin{array}{l}\text { Percentage } \\
(\mathrm{N}=120)^{\star}\end{array}$ \\
\hline $\begin{array}{l}\text { Where to obtain improved seeds/seedlings } \\
\text { Improved crop spacing } \\
\text { How to prepare land for planting } \\
\text { How to apply fertilizer correctly } \\
\text { How to apply herbicides and pesticides correctly } \\
\text { Improved techniques of crop and animal husbandry } \\
\text { Agricultural marketing information } \\
\text { Soil/water conservation practices } \\
\text { Appropriate sources of farm credit } \\
\text { Methods of prevention/control of pests and diseases } \\
\text { Improved storage and processing methods }\end{array}$ & $\begin{array}{l}43.3 \\
3.3 \\
12.5 \\
15.0 \\
11.7 \\
42.5 \\
24.2 \\
14.2 \\
39.2 \\
61.7 \\
25.0\end{array}$ \\
\hline
\end{tabular}

Source: Field survey data (2011).

*Multiple responses

\subsection{Sources of agricultural information mostly used by respondents}

Table 3 shows that the sources of information highly patronised $(M>3)$ by the respondents were produce buyers $(M=3.4)$, inputs dealers $(M=3.3)$, Extension agent $(M=3.2)$ and radio ( $M=2.3$ ) in that order. This implies that the respondents were relying on mostly the traditional sources of information rather than the modern sources like television, newspapers, mobile phones, and the internet which were rarely $(\mathrm{M}<3)$ used. This might be as a result of the low educational level of the farmers.

Table 3: Mean distribution of respondents according to level of use of agricultural information sources

\begin{tabular}{lll}
\hline Sources of agricultural information & Mean score & Ranking \\
\hline Extension agents & $3.2^{*}$ & $3^{\text {rd }}$ \\
Research institutes & 1.3 & $11^{\text {th }}$ \\
Non-governmental organizations & 1.5 & $9^{\text {th }}$ \\
Academic institutions & 1.6 & $8^{\text {th }}$ \\
Fellow farmers & 2.2 & $5^{\text {th }}$ \\
News papers/magazine & 1.7 & $7^{\text {th }}$ \\
Radio & 2.3 & $4^{\text {th }}$ \\
Television & 2.0 & $6^{\text {th }}$ \\
Input dealers & $3.3^{*}$ & $2^{\text {nd }}$ \\
Produce buyers & $3.4^{*}$ & $1^{\text {st }}$ \\
Internet & 1.4 & $10^{\text {th }}$ \\
\hline
\end{tabular}

$$
{ }^{\star} \text { = Highly used. }
$$




\section{Constraints to access and use of agricultural information by the respondents.}

Table 4 shows the mean distribution of respondents according to their constraints to access and use of agricultural information. The factors that were rated as serious constraints $(M>2)$ include poor marketing structure $(M=2.9)$, inadequate number of extension agents $(M=2.5)$, poor communication facilities $(M=2.4)$, lack of farm records $(M=2.2)$ and low educational level $(M=2.1)$. This implies that the respondents were facing serious constraints to access to agricultural information.

Table 4: Mean distribution of respondents according to constraints to access and use of agricultural information.

\begin{tabular}{lll}
\hline Possible constraints & Mean score & Ranking \\
\hline Inadequate number of extension agents & $2.5^{*}$ & $2^{\text {nd }}$ \\
Low educational level & $2.1^{*}$ & $5^{\text {th }}$ \\
Use of foreign language information & 1.9 & $7^{\text {th }}$ \\
Old age of farmers & 1.7 & $9^{\text {th }}$ \\
Poor communication facilities & $2.4^{*}$ & $3^{\text {rd }}$ \\
Lack of farm records & $2.2^{*}$ & $4^{\text {th }}$ \\
High cost of information & 1.8 & $8^{\text {th }}$ \\
Inadequate farm inputs & $2.0^{*}$ & $6^{\text {th }}$ \\
Poor marketing structures & $2.9^{*}$ & $1^{\text {st }}$ \\
\hline
\end{tabular}

${ }^{*}=$ Serious constraints

Source: Field survey data (2011)

Effects of respondents' socioeconomic characteristics on their level of use of
agricultural information

Table 5 shows the regression analysis of the effects of socioeconomic characteristics on level of information sources. The $\mathrm{R}^{2}$ was 0.135 meaning that the independent variables accounted for only $13.5 \%$ in explaining the effect of selected socio-economic characteristics of respondents on the level of utilization of information sources. However, only type of enterprise and household size were significant at $5.0 \%$ level. On the other hand, age, educational level, marital status, farm size, years of farming experience, and amount of credit used by respondents were not significant determinants of the utilization of information sources. This implies that the type farming enterprise and the respondent's farm size were strong determinants of the type and level of information a farmer would use. This finding agrees with those of Aina (1991) and Kaniki (1995) who reported that variables such as education, economic status, geographical location, age, availability of information providers, awareness of the available information providers and accessibility of the information source influence the information needs of farmers. Idrisa et. al, (2006) also found that family size and farming experience of the farmers also affect their information needs. 
Table 5: Regression analysis showing the effect of selected socio-economic characteristics of respondents on the level of utilization of information sources

\begin{tabular}{llllll}
\hline Model & \multicolumn{2}{l}{$\begin{array}{l}\text { Unstandardized } \\
\text { coefficient }\end{array}$} & \multicolumn{4}{l}{$\begin{array}{l}\text { Standardized } \\
\text { coefficient }\end{array}$} \\
\cline { 2 - 6 } & B & S.E & Beta & t-value & Sig \\
\hline Constant & 5.010 & 1.510 & & 3.318 & 0.001 \\
Age (yrs) & -0.034 & 0.038 & -0.159 & -0.892 & 0.374 \\
Educational level & 0.104 & 0.302 & 0.036 & 0.344 & 0.374 \\
Marital status & -0.473 & 0.517 & -0.093 & -0.915 & 0.362 \\
Type of enterprise & 0.834 & 0.470 & 0.170 & 1.777 & $0.078^{*}$ \\
Farm size & 0.047 & 0.099 & 0.053 & 0.481 & 0.632 \\
Household size & 0.111 & 0.065 & 0.231 & 1.709 & $0.090^{*}$ \\
Farming experience & -.0 .036 & 0.034 & 0.182 & -1.042 & 0.301 \\
(yrs) & & & & & \\
Amount of credit used & $5.59 \mathrm{E}-006$ & 0.000 & 0.077 & -0.766 & 0.445 \\
\hline $\mathrm{R}^{2}=0.135$ & & & & & \\
$\mathrm{~F}-$ value $=2.174$ & & & & &
\end{tabular}

Source: Field survey data (2011)

\section{Conclusion}

The respondents in the study area were faced with serious problems of inadequate marketing information, inadequate credit and inadequate number of extension agents that would disseminate reliable agricultural information to farmers. However, the success of small scale farmers in the study area could be attributed to the contribution of extension services.

\section{Recommendation}

Based on the findings from the research, the following recommendations were made:

1. In view of the fact that most farmers in the study area had very low level of education extension agents and other advisory service providers should provide agricultural information in a local language that is understood by the farmers.

2. Government should make more credit facilities available for farmers to be able to access modern information sources. The distribution of free mobile phones to farmers by the Federal government under the growth enhancement scheme (GES) should be replicated by all the states in Nigeria.

3. Government should employ qualified and adequate number of extension agents to provide adequate extension services to farmers.

4. Extension agents should be given special training on the application of ICTs in extension delivery service and be encouraged to use same.

\section{References}

Agbamu J.U (2006). Essentials of Agricultural Communication in Nigeria. Malthouse Press Limited, Lagos. Pp 34-56.

Aina, L.O. (1990). Information African farmers: Some obstacles to information flow. Information Development 6 (4):201-205).

Aina, L.O. (1995). Information and agriculture in Africa. In: Aina, L.O, Kakaniki, A.M. and Ojiambo, J.B. (Eds). Agricultural Information in Africa. World information services Ltd, lbadan. 
Idrisa, Y. L.; Gwary, M.M. and Ibrahim, A. (2006). Adoption of Cassava Farming Technologies in Mubi North Local Government area of Adamawa State, Nigeria. Journal of Agricultural Research Vol. 2 No. 2 Pp26-35.

Kaniki, A.M (1995). Information and Agriculture in Africa, in Aina, L.O, A.M Kaniki and J.B Ojiambo (Eds). Agricultural Information in Africa. World Information Services Ltd, Ibadan Pp 67-69.

Natsa, R.T. (2013). Empowering farmers to achieve gains of transformation agenda. Leadership Newspaper 10 $0^{\text {th }}$ January, 2013. Leadership Newspaper Group, Abuja, Nigeria.

Olawoye, J.E. (1996). Agricultural production in Nigeria. In: Babaloye T. and Okiki, A. (Eds). Utilizing Research Findings to Increase Food Production: What the mass media should do in Taming Hunger: Seminar organized by Oyo State Chapter of the Media Forum for Agriculture, IITA, Ibadan 1996.

Ozowa, V.N. (1995). Information Needs of Small Scale Farmers in Africa: the Nigerian Example, Quarterly Bulletin of the Association of Agricultural Information Specialist. Vol. 40 No 1http/www.world bank. Org. Pp 1-3. 